\title{
Tourniquet-induced tissue hypoxia characterized by near-infrared spectroscopy during ankle surgery: an observational study
}

Liang Lin ${ }^{1}$, Gang Li ${ }^{2}$, Jinlei Li $i^{3}$ and Lingzhong Meng ${ }^{3^{*}}$ (D)

\begin{abstract}
Background: Pneumatic tourniquet inflation during extremity surgery leads to profound and prolonged tissue ischemia. Its effect on tissue oxygenation is inadequately studied.

Methods: Patients undergoing elective ankle surgery with tourniquet application participated in this observational cohort study. Somatic and cerebral tissue oxygen saturation $\left(\mathrm{SstO}_{2}\right.$ and $\left.\mathrm{SctO}_{2}\right)$ were monitored using tissue nearinfrared spectroscopy. Oxygenation was monitored distally $\left(\mathrm{SstO}_{2}\right.$-distal) and proximally to the tourniquet, on the contralateral leg, and the forehead (a total of 4 tissue beds). Tissue oxygenation at different time points was compared. The magnitude, duration, and load (product of magnitude and duration) of tissue desaturation during tourniquet inflation were correlated with tissue resaturation and hypersaturation after tourniquet deflation.

Results: Data of 26 patients were analyzed. The tourniquet inflation time was $120 \pm 31$ mins. Following a rapid desaturation from $77 \pm 8 \%$ pre-inflation to $38 \pm 20 \% 10$ mins post-inflation, $\mathrm{SstO}_{2}$-distal slowly and continuously desaturated and reach the nadir (16 $\pm 11 \%)$ toward the end of inflation. After deflation, $\mathrm{SstO}_{2}$-distal rapidly resaturated from $16 \pm 11 \%$ to $91 \pm 5 \%$ (i.e., hypersaturation); $\mathrm{SstO}_{2}$ monitored proximally to the tourniquet and on contralateral leg had significant but small desaturation $(\sim 2-3 \%, p<0.001)$; in contrast, $\mathrm{SctO}_{2}$ remained stable. The desaturation load had a significant correlation with resaturation magnitude $(p<0.001)$; while the desaturation duration had a significant correlation with hypersaturation magnitude $(p=0.04)$.
\end{abstract}

Conclusions: Tissue dys-oxygenation following tourniquet application can be reliably monitored using tissue oximetry. Its outcome significance remains to be determined.

Keywords: Tissue oxygenation, Tourniquet, Ischemia, Hypoxia

\section{Background}

A pneumatic tourniquet is commonly employed during extremity surgery to reduce blood loss and facilitate the surgeon's operation (i.e., a bloodless surgical field). It is intriguing when considering that, although the blood flow is completely or near-completely stopped for a prolonged period, the tissue beds distal to the tourniquet are still alive afterward. In theory, the ischemic tissue would become hypoxic, and the hypoxia would become

\footnotetext{
*Correspondence: meng.lingzhong@gmail.com

${ }^{3}$ Department of Anesthesiology, Yale University School of Medicine, 333

Cedar Street, TMP 3, P.O. Box 208051, New Haven, CT 06520, USA

Full list of author information is available at the end of the article
}

progressively worse, following the interruption of blood flow as long as the tissue continues to consume oxygen albeit maybe at a much slower rate as a result of the adaptive changes or other factors such as anesthesia [1, 2]. It is enlightening if the change in tissue oxygenation following tourniquet inflation is continuously monitored. The modern tissue oximetry based on near-infrared spectroscopy enables non-invasive, bedside and continuous measurement of the hemoglobin oxygen saturation of the mixed arterial, capillary, and venous blood in the tissue bed that is $\sim 2-2.5 \mathrm{~cm}$ below the probe. Cerebral tissue oxygen saturation $\left(\mathrm{SctO}_{2}\right)$ monitored on the forehead has been used in clinical care for $20+$ years in

(c) The Author(s). 2019 Open Access This article is distributed under the terms of the Creative Commons Attribution 4.0 International License (http://creativecommons.org/licenses/by/4.0/), which permits unrestricted use, distribution, and 
patients having surgery [3] and cardiac arrest [4]; in contrast, the clinical application of somatic tissue oxygen saturation $\left(\mathrm{SstO}_{2}\right)$, monitored at a peripheral location, is relatively new $[5,6]$. The goal of this prospective cohort study was to characterize the tissue dys-oxygenation related to tourniquet application during ankle surgery. The secondary objective was to correlate parameters derived during tourniquet inflation with parameters derived following tourniquet deflation to explore the potential direction for future research.

\section{Methods}

This observational analytic cohort study was approved by the Institutional Review Board for clinical investigations at Yale University, New Haven, Connecticut, USA. Consent to participate in the study was obtained from all patients before surgery.

\section{Patients and anesthesia}

The inclusion criteria were: 1) elective ankle surgery for non-diabetic-related injuries, 2) tourniquet application, and 3) American Society of Anesthesiologists (ASA) physical status score $\leq$ III. The exclusion criteria were: 1 ) patient refusal, 2) urgent or emergent surgery, 3) age $<$ 18 years, 4) diabetic foot, 5) peripheral vascular disease, 6) skin condition unsuitable for adhesive oximetry probe, 7) pregnancy and 8) existing neuropathy or myopathy.

All patients received ultrasound-guided peripheral nerve blockade using an insulated needle before surgery. Patients were monitored with electrocardiogram, pulse oximetry, and non-invasive blood-pressure, supplemented with $21 / \mathrm{min}$ oxygen by nasal cannula, and pre-medicated with intravenous $1-2 \mathrm{mg}$ midazolam and 50-100 $\mu \mathrm{g}$ fentanyl. A single-shot popliteal, sciatic, and saphenous nerve block were performed under in-plane technique with a total of $30 \mathrm{ml} 0.5 \%$ ropivacaine. Upon arriving at the operating room and following anesthesia induction with intravenous lidocaine, fentanyl and propofol administration, either an endotracheal tube or laryngeal mask airway, at the discretion of the anesthesia team, was placed. Anesthesia was maintained using sevoflurane. The tourniquet was placed on the upper leg and inflated to $300 \mathrm{mmHg}$ during surgery in all patients.

\section{Tissue oxygenation monitoring}

Tissue oxygenation was monitored using a tissue oximeter based on near-infrared spectroscopy (NIRS) (FORE-SIGHT Elite, CASMED, Inc., Branford, Connecticut). In essence, NIRS-measured tissue oxygenation is determined by the balanced between oxygen consumption and supply of the tissue bed which is about 2$2.5 \mathrm{~cm}$ below the interrogating probe. In this study, four different tissue beds were monitored in each patient: 1 ) $\mathrm{SstO}_{2}$ distal to the tourniquet $\left(\mathrm{SstO}_{2}\right.$-distal) with the probe placed on the back of the lower leg and about 4 fingers below the popliteal crease; 2) $\mathrm{SstO}_{2}$ proximal to the tourniquet $\left(\mathrm{SstO}_{2}\right.$-prox $)$ with the probe placed on the front of the upper leg and about 6 fingers below the femoral crease; 3) $\mathrm{SstO}_{2}$ on the contralateral leg $\left(\mathrm{SstO}_{2}-\right.$ contra) at the same location as $\mathrm{SstO}_{2}$-distal; 4) $\mathrm{SctO}_{2}$ with the probe placed on the forehead. Monitoring and data recording started before anesthesia induction and stopped at the end of surgery.

\section{Data recording and analysis}

Tissue oxygenation of different tissue beds was simultaneously and continuously recorded into an excel worksheet by a research laptop at a frequency of one new data point every $2 \mathrm{~s}$. The medians of tissue oxygenation within each minute were used in the analysis. The time points of interest were: immediately before tourniquet inflation $\left(\mathrm{T}_{0}\right), 5$ mins $\left(\mathrm{T}_{5}\right), 10 \mathrm{mins}\left(\mathrm{T}_{10}\right), 20 \mathrm{mins}\left(\mathrm{T}_{20}\right)$, 30 mins $\left(T_{30}\right)$, and 60 mins $\left(T_{60}\right)$ after tourniquet inflation, immediately before tourniquet deflation ( $\left.\mathrm{T}_{\text {end }}\right)$, and 3-5 min after tourniquet deflation ( $\left.\mathrm{T}_{\text {post }}\right)$. The hypoxic load, defined as the product of the magnitude and duration of tissue desaturation, is quantified by the area under the curve (AUC) encircled by the actual tracing and the straight line of the baseline value $\left(\mathrm{T}_{0}\right)$.

\section{Statistical analysis}

As an exploratory observational study, a power analysis was not performed before the study. Data are expressed as mean $\pm \mathrm{SD}$. Paired Student's t-test was used when comparing the changes in tissue oxygenation of the same tissue bed. The correlation between the variables before tourniquet deflation (baseline oxygenation $\left(\mathrm{T}_{0}\right)$, maximal hypoxia ( $\mathrm{T}_{\text {end }}$ ), hypoxic duration, and hypoxic load (AUC)) and the variables after tourniquet deflation (resaturation magnitude $\left(\Delta \mathrm{T}_{\text {post-end }}\right)$, resaturation rate (\%/second), and hyperemic response $\left.\left(\Delta \mathrm{T}_{\text {post-0 }}\right)\right)$ was analyzed using Pearson's correlation coefficient. The $p$ value $<0.05$ was considered significant. Statistical analyses were performed using SPSS software (ver. 22.0 for Windows; SPSS Inc., Chicago, IL).

\section{Results}

Thirty-one patients participated in this study. Five patients were excluded from the analysis due to incomplete data $(n=4)$ and conversion of ankle surgery to below-knee amputation $(n=1)$. Data of 26 patients were included in the final analysis. The patient's demographic data and past medical history were summarized in Table 1. All patients had a tourniquet application, with an average duration of $120 \pm 31$ mins.

Tissue oxygenation of different tissue beds was summarized in Table 2 and illustrated by Fig. 1. Tourniquet inflation led to a rapid decrease of $\mathrm{SstO}_{2}$-distal 
Table 1 Demographics, tourniquet time and co-morbidities of the study population $(n=26)$

\begin{tabular}{|c|c|}
\hline Variables & Value \& count \\
\hline Age (year) & $48 \pm 15$ \\
\hline Sex $=$ male $(n(\%))$ & $16(62 \%)$ \\
\hline Weight (kg) & $89 \pm 23$ \\
\hline Height (cm) & $173 \pm 10$ \\
\hline BMl & $30 \pm 7$ \\
\hline$A S A \geq \|(n(\%))$ & 19 (73\%) \\
\hline Leg $=$ right $(n(\%))$ & $22(85 \%)$ \\
\hline Hypertension (n (\%)) & $8(31 \%)$ \\
\hline Diabetes mellitus (n (\%)) & $3(12 \%)$ \\
\hline Peripheral vascular disease (n (\%)) & $1(6 \%)$ \\
\hline Chronic lung disease (n (\%)) & $6(23 \%)$ \\
\hline Cardiovascular diseases (n (\%)) & $1(6 \%)$ \\
\hline
\end{tabular}

$B M I$ body mass index, ASA American Society of Anesthesiologists

from $77 \pm 8 \%$ pre-inflation to $38 \pm 20 \% \quad 10$ mins post-inflation $\left(51 \%\right.$ relative decrease). $\mathrm{SstO}_{2}$-distal slowly, but continuously, trended downward (i.e., desaturation) throughout the rest of the inflation period and did not reach the nadir $(16 \pm 11,79 \%$ relative decrease) until immediately before the tourniquet deflation. Following tourniquet deflation, there was a rapid increase (469\% relative increase) of $\mathrm{SstO}_{2}$-distal from the nadir of $16 \pm 11 \%$ to the peak of $91 \pm 5 \%$ about 3-5 min post-deflation (i.e., resaturation). The difference between the post-deflation peak value $\left(\mathrm{T}_{\text {post }}\right)$ and the pre-inflation baseline value $\left(\mathrm{T}_{0}\right)$ of $\mathrm{SstO}_{2}$-distal was $14 \pm 8 \% \quad(18 \%$ relative increase) (i.e., hyperemia) (Table 3).

The oxygenation of other tissue beds, including $\mathrm{SstO}_{2}$-prox, $\mathrm{SstO}_{2}$-contra and $\mathrm{SctO}_{2}$, remained stable throughout the ischemic period from $\mathrm{T}_{0}$ to $\mathrm{T}_{\text {end }}$. The tourniquet deflation led to a relative decrease of both $\mathrm{SstO}_{2}$-prox and $\mathrm{SstO}_{2}$-contra of $3-4 \%(p<0.05)$; in contrast, $\mathrm{SctO}_{2}$ remained relatively stable following tourniquet deflation, albeit it had a small increase in the 21-year old patient illustrated in Fig. 2.
The resaturation magnitude $\left(\Delta \mathrm{T}_{\text {post-end }}\right)$ had a significant correlation with maximal hypoxia $\left(\mathrm{T}_{\text {end }}\right)$ $(p<0.001)$ and hypoxic load (AUC) $(p<0.001)$. The resaturation rate $(\% /$ second) had a significant correlation with maximal hypoxia $\left(\mathrm{T}_{\text {end }}\right)(p=0.03)$. The hyperemic response $\left(\Delta \mathrm{T}_{\text {post-0 }}\right)$ had a significant correlation with both baseline oxygenation $\left(\mathrm{T}_{0}\right)(p<0.001)$ and hypoxic duration $(p=0.04)$.

\section{Discussion}

This study showed that extreme tissue hypoxia incurred by tourniquet application can be reliably and continuously measured using NIRS-based tissue oximetry. The hypoxic load (AUC) is significantly associated with the magnitude of the reperfusion-related resaturation $\left(\Delta \mathrm{T}_{\text {post-end }}\right)$, but not the rebound hyperemia $\left(\Delta \mathrm{T}_{\text {post- } 0}\right)$. In comparison, the ischemic time is significantly associated with the rebound hyperemia $\left(\Delta \mathrm{T}_{\text {post-0 }}\right)$, but not the magnitude of resaturation $\left(\Delta \mathrm{T}_{\text {post-end }}\right)$. The magnitudes, durations, and loads of tissue hypoxia during tourniquet inflation vary among different patients; however, the clinical significance of these parameters remains to be determined.

In 1904, Harvey Cushing first described the clinical application of pneumatic tourniquet [7]. Tourniquet is currently widely used during upper and lower extremity surgery to facilitate the surgeon's operation by rendering a bloodless surgical field. It is a milestone event in medical history. However, tourniquet is not risk-free. Various post-tourniquet complications have been reported such as nerve palsy [8], vascular injuries [9], wound hypoxia [10], abnormal electromyography and muscle weakness [11]. If given enough time, the tissues that are distal to the tourniquet will eventually die. However, the time limit of safe tourniquet inflation during extremity surgery remains controversial [12-14]. The dogma of 90 mins is based on animal studies $[15,16]$. In patients undergoing knee surgery, Gidlöf et al. showed that tourniquet-induced prolonged ischemia (90-180 $\mathrm{min}$ ) led to a progressively worsening endothelial injury [17]. Many other studies showed that tourniquet-induced extreme ischemia $(>4 \mathrm{~h})$ can lead to irreversible skeletal muscle injury $[18,19]$.

Table 2 Absolute values and changes of somatic tissue oxygen saturation $\left(\mathrm{SstO}_{2}\right)$ and cerebral tissue oxygen saturation $\left.(\mathrm{SctO})_{2}\right)$ at different time points $(n=26)$

\begin{tabular}{llllll}
\hline & $\mathrm{T}_{0}$ & $\mathrm{~T}_{\text {end }}$ & $\mathrm{T}_{\text {post }}$ & $\Delta \mathrm{T}_{\text {post-0 }}{ }^{\mathrm{a}}$ & $\Delta \mathrm{T}_{\text {post-end }}{ }^{\mathrm{b}}$ \\
\hline $\mathrm{SstO}_{2}$-distal (\%) & $77.5 \pm 7.7$ & $15.6 \pm 9.7$ & $90.9 \pm 4.0$ & $13.8 \pm 8.0^{*}$ & $75.4 \pm 11.5^{*}$ \\
$\mathrm{SstO}_{2}$-prox (\%) & $82.3 \pm 6.1$ & $81.1 \pm 7.8$ & $78.4 \pm 7.3$ & $-3.6 \pm 4.5^{*}$ & $-2.7 \pm 2.3^{*}$ \\
$\mathrm{SstO}_{2}$-contra (\%) & $81.2 \pm 6.8$ & $81.3 \pm 10.0$ & $78.3 \pm 10.5$ & $-5.6 \pm 6.3^{*}$ & $-3.0 \pm 3.2^{*}$ \\
$\mathrm{SctO}_{2}$ (\%) & $77.5 \pm 6.2$ & $79.9 \pm 7.9$ & $80.1 \pm 8.0$ & $2.0 \pm 6.3$ & $0.2 \pm 2.7$ \\
\hline
\end{tabular}

$\mathrm{SstO}_{2}$-distal $=\mathrm{SstO}_{2}$ distal to the tourniquet; $\mathrm{SstO}_{2}$-prox $=\mathrm{SstO}_{2}$ proximal to the tourniquet; $\mathrm{SstO}_{2}$-contra $=\mathrm{SstO}_{2}$ on the contralateral leg; $\mathrm{T}_{0}=\mathrm{immediately}_{\text {before }}$ tourniquet insufflation; $\mathrm{T}_{\text {end }}=$ immediately before tourniquet deflation; $\mathrm{T}_{\text {post }}=3-5 \mathrm{~min}$ after tourniquet deflation

${ }^{*} P<0.001$

apaired Student's t-test between $T_{\text {post }}$ and $T_{0}$

baired Student's t-test between $T_{\text {post }}$ and $T_{\text {end }}$ 


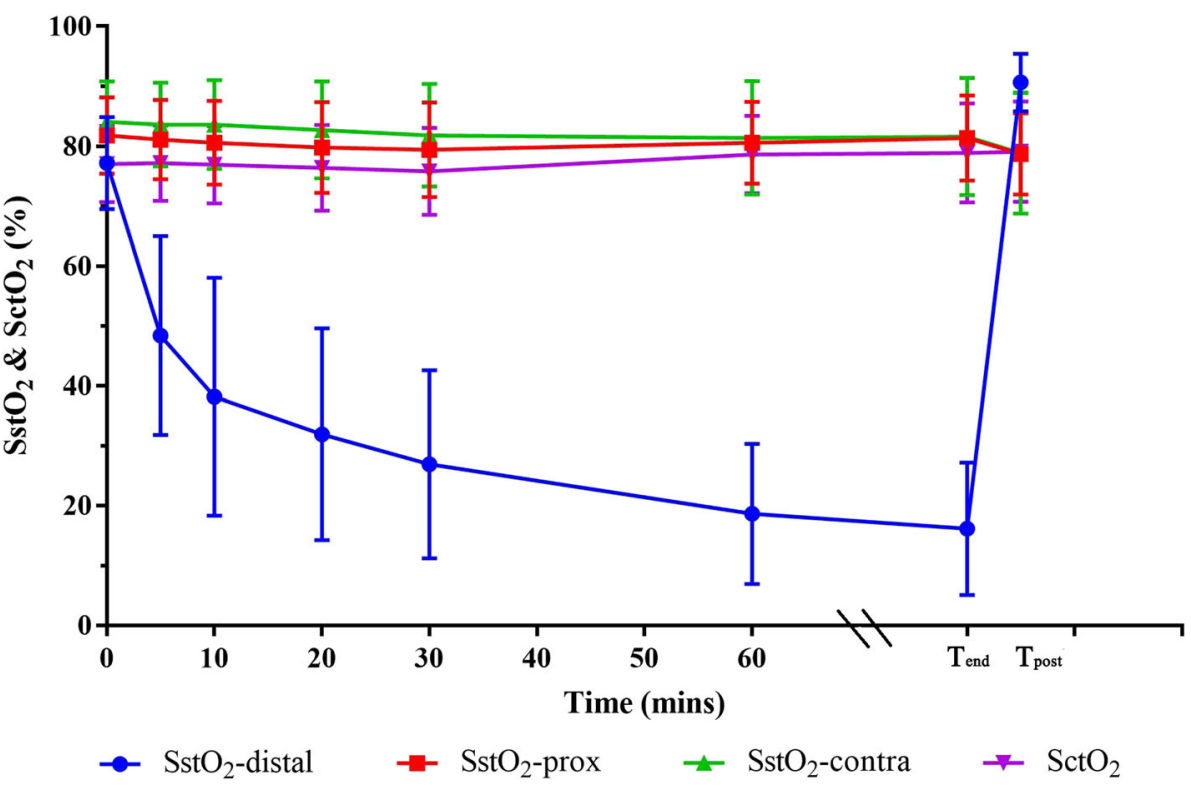

Fig. 1 Group mean and standard deviation of somatic tissue oxygen saturation $\left(\mathrm{SstO}_{2}\right)$ monitored distal $\left(\mathrm{SstO}_{2}\right.$-distal) and proximal $\left(\mathrm{SstO} \mathrm{O}_{2}\right.$-prox) to the tourniquet and on the contralateral leg $\left(\mathrm{SstO}_{2}-\mathrm{Contra}\right)$ and cerebral tissue oxygen saturation $\left(\mathrm{SctO}_{2}\right)$ monitored on the forehead at different time points. $T_{\text {end }}=$ time point at the end of tourniquet inflation; $T_{\text {post }}=$ time point 3-5 min after tourniquet deflation

The effect of tourniquet inflation on NIRS-measured tissue oxygenation in humans has been previously reported [20]. However, the tissue beds monitored and the research aims in these studies are different from our study. The study performed by Song et al. monitored cerebral, not somatic, tissue bed in patients undergoing total knee replacement surgery [21]. Tujjar et al. only monitored the tissue bed that was distal to the tourniquet in patients undergoing upper extremity surgery [22]. In healthy volunteers, Muellner et al. studied the effects of different tourniquet inflation pressures on tissue oxygenation based on the monitoring of the tissue bed distal to the tourniquet only [23]. In patients undergoing ankle fracture repair, Shadgan et al. studied the relationship between tissue oxygenation and oxidative muscle injury based on the monitoring of the tissue beds distal to the tourniquet and on the contralateral leg [24].
The reactive hyperemia following tourniquet release is a well-documented phenomenon [25]. De Backer and Durand advocated the use of reactive hyperemia as an indicator of the microvascular reserve [26], as corroborated by the observation that the magnitude of reactive hyperemia is reduced in septic patients compared with control subjects [27]. In a rat model, Kim et al. showed that NIRS-measured tissue oxygenation had an overshoot (i.e., higher than baseline) following a 2-h, not 3-h tourniquet inflation, suggesting an association between the duration of ischemia and the magnitude of hyperemic response [28].

The severity of tourniquet-induced ischemia is traditionally gauged by the duration of tourniquet inflation. However, this approach may have overlooked the dynamic nature of tissue ischemia in an individual patient and the variability of ischemic severity among different patients, as suggested by both our study and the previous

Table 3 Association of representative variables of tissue oxygenation with variables of resaturation and hyperemia following tourniquet deflation $(n=26)$

\begin{tabular}{|c|c|c|c|c|c|c|}
\hline \multirow[t]{2}{*}{ Variable } & \multicolumn{2}{|c|}{ Resaturation magnitude ( $\left.\Delta T_{\text {post-end }}\right)$} & \multicolumn{2}{|c|}{ Resaturation rate (\%/second) } & \multicolumn{2}{|c|}{ Hyperemic response $\left(\Delta T_{\text {post- } 0}\right.$} \\
\hline & $R$ value & $P$ value & $R$ value & $P$ value & $R$ value & $P$ value \\
\hline Baseline oxygenation $\left(T_{0}\right)$ & 0.02 & 0.92 & -0.01 & 0.95 & -0.87 & $<0.001$ \\
\hline Maximal hypoxia $\left(T_{\text {end }}\right)$ & -0.94 & $<0.001$ & 0.43 & 0.03 & -0.19 & 0.34 \\
\hline Hypoxic duration & 0.26 & 0.20 & -0.17 & 0.41 & 0.41 & 0.04 \\
\hline Hypoxic load (AUC) & 0.66 & $<0.001$ & -0.08 & 0.70 & 0.09 & 0.68 \\
\hline
\end{tabular}

$\mathrm{T}_{0}=$ immediately before tourniquet insufflation; $\mathrm{T}_{\text {end }}=$ immediately before tourniquet deflation; $\mathrm{T}_{\text {post }}=3-5$ min after tourniquet deflation. $\Delta \mathrm{T}_{\text {post-end }}=$ difference between tissue oxygenation immediately before and after tourniquet deflation; $\Delta \mathrm{T}_{\text {post-0 }}=$ difference between tissue oxygenation immediately after tourniquet deflation and before tourniquet inflation (baseline); AUC = area under curve 


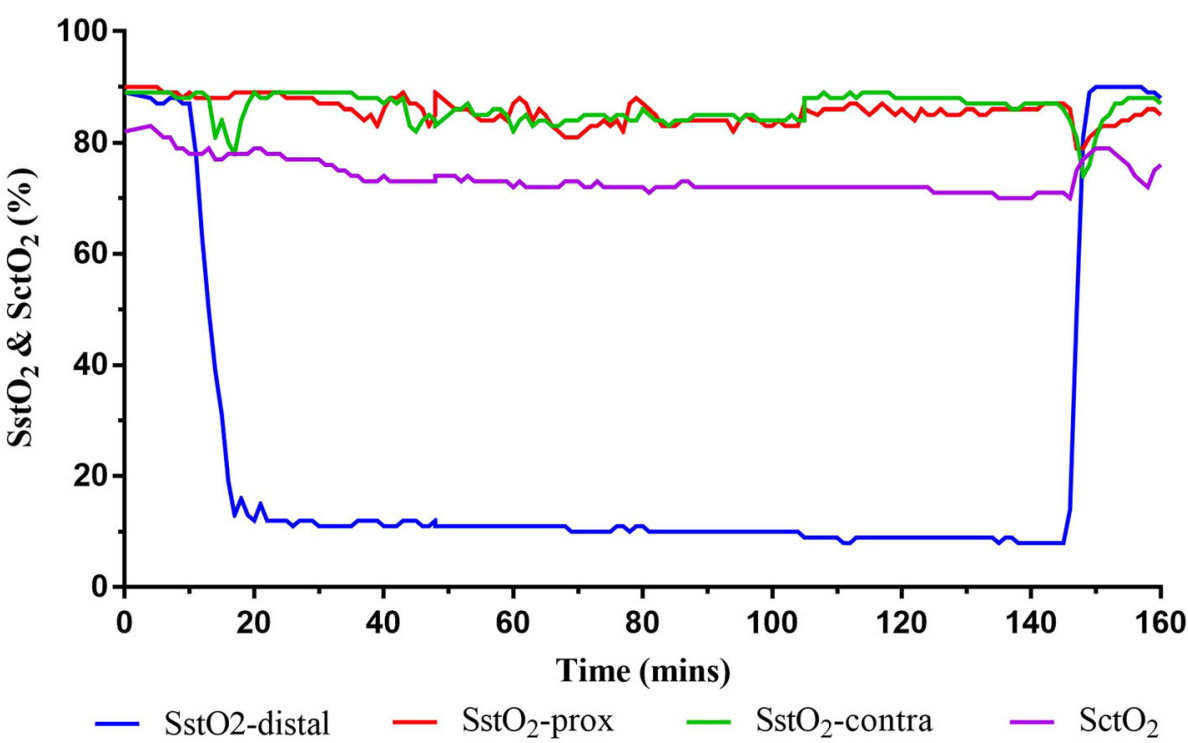

Fig. 2 Real-time tracing of somatic tissue oxygen saturation $\left(\mathrm{SstO}_{2}\right)$ monitored distal $\left(\mathrm{SstO}_{2}\right.$-distal) and proximal $\left(\mathrm{SstO}_{2}\right.$-prox) to the tourniquet and on the contralateral leg $\left(\mathrm{SstO}_{2}\right.$-contra) and cerebral tissue oxygen saturation $\left(\mathrm{SctO}_{2}\right)$ monitored on the forehead in a 21-year old college student

studies [21-24]. Moreover, the consequence of tissue ischemia is determined not only by the ischemic duration, but also the metabolic demand as suggested by the association between slow energy consumption and delayed ultrastructural damage in the canine ischemic model [29]. Tissue oximetry, which measures the balance between tissue oxygen consumption and supply continuously and non-invasively, is a promising technology in assessing the severity of tourniquet-induced ischemia in individual patients.

Skeletal muscle can rapidly adjust its energy expenditure and production during acute ischemia [30,31]. The ATPs reserved in muscle fibers only last for a few seconds [32]. However, the skeletal muscle can remarkably replenish energy via two distinctive anaerobic pathways. The pathway of anaerobic glycolysis can sustain muscle activity for a few minutes [33]; while the pathway of phosphocreatine degradation can sustain muscle activity from minutes to hours [34]. As a result, the ATPs in skeletal muscle fall at a very low rate during the first 3$4 \mathrm{~h}$ of ischemia $[35,36]$. However, tissue damage characterized by cell necrosis and apoptosis eventually ensues about $6-7 \mathrm{~h}$ after the onset of ischemia when the glycogen and phosphocreatine reserves are exhausted [37].

An interesting observation of our study is the rapid desaturation for about 10 mins followed by a slow but continuous desaturation for the remaining ischemic period in the tissue bed distal to tourniquet. This phenomenon may be secondary to the adaptive adjustment of metabolic activity made by primarily muscular tissue. Although $\mathrm{SctO}_{2}$ remained stable following tourniquet deflation based on the average of all patients, the 21-year-old physically fit college student had a notable increase in $\mathrm{SctO}_{2}$, a change different to most other patients (Fig. 2). It may relate to the metabolites (including carbon dioxide) generated by the ischemic tissue which were flushed into cerebral circulation and led to cerebral vasodilation following tourniquet deflation. This 21-year-old young patient may have a more robust cerebral vasoreactivity to carbon dioxide than older patients (the average age of all patients $=48$ years). Nonetheless, the exact cause and the clinical significance of this outlier remain to be elucidated.

This study did not evaluate the complications associated tourniquet application and thus cannot tell the relationship between tissue NIRS parameters and ischemia-related outcomes. This is a major limitation of our study. Also, all patients in our study had a peripheral nerve block, which makes it difficult to extrapolate the findings of this study in patients without nerve block. We found a considerable variation in both the rate and magnitude of tissue desaturation following tourniquet inflation. One of the potential causes of this inter-individual variation may relate to the thickness of the skin and subcutaneous tissue because thick superficial layers may preclude the near-infrared light from interrogating the deeper muscular tissue.

\section{Conclusion}

NIRS-based tissue oximetry can reliably and continuously measure tissue desaturation, resaturation and hypersaturation during tourniquet application. The desaturation load is associated the magnitude of 
resaturation; while the desaturation duration is associate with the magnitude of hypersaturation. The clinical value of tissue oximetry in patients receiving tourniquet application needs to be determined by future research.

\begin{abstract}
Abbreviations
$\Delta T_{\text {post- } 0}: T_{\text {post }}-T_{0} ; \Delta T_{\text {post-end }}: T_{\text {post }}-T_{\text {endi }}$ AUC: Area under the curve; $\mathrm{SctO}_{2}$ : Cerebral tissue oxygen saturation; $\mathrm{StO}_{2}$ : Somatic tissue oxygen saturation; $\mathrm{SstO}_{2}$-contra: $\mathrm{SstO}_{2}$ on the contralateral leg; $\mathrm{SstO}_{2}$-distal: $\mathrm{SstO}_{2}$ distal to the tourniquet; $\mathrm{SstO}_{2}$-prox: $\mathrm{SstO}_{2}$ proximal to the tourniquet; $\mathrm{T}_{0}$ : Immediately before tourniquet insufflation; $\mathrm{T}_{\text {end: }}$ Immediately before tourniquet deflation; $T_{\text {post }}$ : 3-5 min after tourniquet deflation
\end{abstract}

\section{Acknowledgements}

The authors would like to acknowledge CAS Medical Systems, Inc., Branford, Connecticut, USA, for providing the FORE-SIGHT ELITE Tissue Oximeter at no cost.

\section{Funding}

This study was funded solely by departmental resources.

\section{Availability of data and materials}

Study data is available upon contact of Dr. Lingzhong Meng by email.

\section{Authors' contributions}

LL: Study design, data collection, data analysis, initial draft, approval of manuscript. GL: Data collection, critical revision and approval of manuscript. $J L$ : Patient recruitment, critical revision and approval of manuscript. LM: Study design, patient recruitment, critical revision and approval of manuscript. All authors have read and approved the manuscript.

\section{Ethics approval and consent to participate}

This study was approved by the Internal Review Board at Yale University and patients gave written informed consent for study participation.

\section{Consent for publication}

Not applicable.

\section{Competing interests}

Lingzhong Meng is a consultant to CAS Medical Systems, Inc. The other authors declare that they have no competing interests.

\section{Publisher's Note}

Springer Nature remains neutral with regard to jurisdictional claims in published maps and institutional affiliations.

\section{Author details \\ 'Department of Anesthesiology, The First Affiliated Hospital, Xiamen University, Xiamen, Fujian Province, China. ${ }^{2}$ Department of Anesthesiology, Peking University Third Hospital, Beijing, China. ${ }^{3}$ Department of Anesthesiology, Yale University School of Medicine, 333 Cedar Street, TMP 3, P.O. Box 208051, New Haven, CT 06520, USA.}

\section{Received: 25 January 2019 Accepted: 18 April 2019} Published online: 10 May 2019

\section{References}

1. Mars M, Gregory MA. A histometric analysis of skeletal myofibers following 90 min of tourniquet ischemia and reperfusion. J Surg Res. 1991;50(2):191-5.

2. Hogan MC, Kurdak SS, Arthur PG. Effect of gradual reduction in $\mathrm{O} 2$ delivery on intracellular homeostasis in contracting skeletal muscle. J Appl Physiol (1985). 1996;80(4):1313-21.

3. Meng L, Gruenbaum SE, Dai F, Wang T. Physiology, intervention, and outcome: three critical questions about cerebral tissue oxygen saturation monitoring. Minerva Anestesiol. 2018;84(5):599-614.

4. Sanfilippo F, Serena G, Corredor C, Benedetto U, Maybauer MO, Al-Subaie N, Madden B, Oddo M, Cecconi M. Cerebral oximetry and return of spontaneous circulation after cardiac arrest: a systematic review and metaanalysis. Resuscitation. 2015;94:67-72.
5. Meng L, Xiao J, Gudelunas K, Yu Z, Zhong Z, Hu X. Association of intraoperative cerebral and muscular tissue oxygen saturation with postoperative complications and length of hospital stay after major spine surgery: an observational study. Br J Anaesth. 2017;118(4):551-62.

6. Li G, Lin L, Dai F, Guo X, Meng L. Muscular tissue oxygen saturation during robotic hysterectomy and postoperative nausea and vomiting: exploring the potential therapeutic thresholds. J Clin Monit Comput. 2018.

7. Bolton CF, McFarlane RM. Human pneumatic tourniquet paralysis. Neurology. 1978;28(8):787-93.

8. Horlocker T, Hebl JR, Gali B, Jankowski CJ, Burkle CM, Berry DJ, Zepeda FA, Stevens SR, Schroeder DR. Anesthetic, patient, and surgical risk factors for neurologic complications after prolonged total tourniquet time during total knee arthroplasty. Anesth Analg. 2006;102(3):950-5.

9. Kumar SN, Chapman JA, Rawlins I. Vascular injuries in total knee arthroplasty. A review of the problem with special reference to the possible effects of the tourniquet. J Arthroplast. 1998;13(2):211-6.

10. Clarke MT, Longstaff L, Edwards D, Rushton N. Tourniquet-induced wound hypoxia after total knee replacement. J Bone Joint Surg Br. 2001;83(1):40-4.

11. Saunders KC, Louis DL, Weingarden SI, Waylonis GW. Effect of tourniquet time on postoperative quadriceps function. Clin Orthop Relat Res. 1979(143):194-9.

12. Wakai A, Winter DC, Street JT, Redmond PH. Pneumatic tourniquets in extremity surgery. J Am Acad Orthop Surg. 2001;9(5):345-51.

13. Chiu D, Wang HH, Blumenthal MR. Creatine phosphokinase release as a measure of tourniquet effect on skeletal muscle. Arch Surg. 1976;111(1):71-4.

14. Appell HJ, Gloser S, Duarte JA, Zellner A, Soares JM. Skeletal muscle damage during tourniquet-induced ischaemia. The initial step towards atrophy after orthopaedic surgery? Eur J Appl Physiol Occup Physiol. 1993;67(4):342-7.

15. Mohler LR, Pedowitz RA, Myers RR, Ohara WM, Lopez MA, Gershuni DH. Intermittent reperfusion fails to prevent posttourniquet neurapraxia. J Hand Surg Am. 1999;24(4):687-93.

16. Heppenstall RB, Scott R, Sapega A, Park YS, Chance B. A comparative study of the tolerance of skeletal muscle to ischemia. Tourniquet application compared with acute compartment syndrome. J Bone Joint Surg Am. 1986; 68(6):820-8.

17. Gidlof $A$, Lewis $D H$, Hammersen $F$. The effect of prolonged total ischemia on the ultrastructure of human skeletal muscle capillaries. A morphometric analysis. Int J Microcirc Clin Exp. 1988;7(1):67-86.

18. Harris K, Walker PM, Mickle DA, Harding R, Gatley R, Wilson GJ, Kuzon B, McKee N, Romaschin AD. Metabolic response of skeletal muscle to ischemia. Am J Phys. 1986;250(2 Pt 2):H213-20.

19. Paradis S, Charles AL, Meyer A, Lejay A, Scholey JW, Chakfe N, Zoll J, Geny B. Chronology of mitochondrial and cellular events during skeletal muscle ischemia-reperfusion. Am J Physiol Cell Physiol. 2016;310(11):C968-82.

20. Palanca AA, Yang A, Bishop JA. The effects of limb elevation on muscle oxygen saturation: a near-infrared spectroscopy study in humans. PM R. 2016;8(3):221-4

21. Song I, Kim DY, Kim YJ. The effect of tourniquet deflation on hemodynamics and regional cerebral oxygen saturation in aged patients undergoing total knee replacement surgery. Korean J Anesthesiol. 2012;63(5):425-30.

22. Tujjar O, De Gaudio AR, Tofani L, Di Filippo A. Effects of prolonged ischemia on human skeletal muscle microcirculation as assessed by near-infrared spectroscopy. J Clin Monit Comput. 2016.

23. Muellner T, Nikolic A, Schramm W, Vecsei V. New instrument that uses nearinfrared spectroscopy for the monitoring of human muscle oxygenation. J Trauma. 1999;46(6):1082-4

24. Shadgan B, Reid WD, Harris RL, Jafari S, Powers SK, O'Brien PJ. Hemodynamic and oxidative mechanisms of tourniquet-induced muscle injury: near-infrared spectroscopy for the orthopedics setting. J Biomed Opt. 2012;17(8):081408-1.

25. Fahmy NR, Patel DG. Hemostatic changes and postoperative deep-vein thrombosis associated with use of a pneumatic tourniquet. J Bone Joint Surg Am. 1981;63(3):461-5.

26. De Backer D, Durand A. Monitoring the microcirculation in critically ill patients. Best Pract Res Clin Anaesthesiol. 2014;28(4):441-51.

27. Neviere R, Mathieu D, Chagnon JL, Lebleu N, Millien JP, Wattel F. Skeletal muscle microvascular blood flow and oxygen transport in patients with severe sepsis. Am J Respir Crit Care Med. 1996;153(1):191-5.

28. Kim JG, Lee J, Roe J, Tromberg BJ, Brenner M, Walters TJ. Hemodynamic changes in rat leg muscles during tourniquet-induced ischemia-reperfusion injury observed by near-infrared spectroscopy. Physiol Meas. 2009;30(7):529-40. 
29. Murry CE, Richard VJ, Reimer KA, Jennings RB. Ischemic preconditioning slows energy metabolism and delays ultrastructural damage during a sustained ischemic episode. Circ Res. 1990;66(4):913-31.

30. Timmons JA, Gustafsson T, Sundberg CJ, Jansson E, Hultman E, Kaiiser L, Chwalbinska-Moneta J, Constantin-Teodosiu D, Macdonald IA, Greenhaff PL. Substrate availability limits human skeletal muscle oxidative ATP regeneration at the onset of ischemic exercise. J Clin Invest. 1998;101(1):79-85.

31. Blei ML, Conley KE, Kushmerick MJ. Separate measures of ATP utilization and recovery in human skeletal muscle. J Physiol. 1993;465:203-22.

32. Lewis SF, Haller RG. Skeletal muscle disorders and associated factors that limit exercise performance. Exerc Sport Sci Rev. 1989;17:67-113.

33. Hultman E, Spriet LL. Skeletal muscle metabolism, contraction force and glycogen utilization during prolonged electrical stimulation in humans. Physiol. 1986;374:493-501.

34. Frontera WR, Ochala J. Skeletal muscle: a brief review of structure and function. Calcif Tissue Int. 2015;96(3):183-95.

35. Walker PM. Ischemia/reperfusion injury in skeletal muscle. Ann Vasc Surg. 1991;5(4):399-402.

36. Kuzon WM Jr, Walker PM, Mickle DA, Harris KA, Pynn BR, McKee NH. An isolated skeletal muscle model suitable for acute ischemia studies. J Surg Res. 1986;41(1):24-32.

37. Troitzsch D, Moosdorf R, Hasenkam JM, Nygaard H, Vogt S. Effects of cyclosporine pretreatment on tissue oxygen levels and cytochrome oxidase in skeletal muscle ischemia and reperfusion. Shock. 2013;39(2):220-6.

Ready to submit your research? Choose BMC and benefit from:

- fast, convenient online submission

- thorough peer review by experienced researchers in your field

- rapid publication on acceptance

- support for research data, including large and complex data types

- gold Open Access which fosters wider collaboration and increased citations

- maximum visibility for your research: over $100 \mathrm{M}$ website views per year

At $\mathrm{BMC}$, research is always in progress.

Learn more biomedcentral.com/submissions 